Marquette University

e-Publications@Marquette

College of Communication Faculty Research and

Publications

Communication, College of

$1-1-2012$

\title{
The Ethics of Lobbying: Testing an Ethical Framework for Advocacy in Public Relations
}

Kati Tusinski Berg

Marquette University, kati.berg@marquette.edu

Accepted version. Journal of Mass Media Ethics, Vol. 27, No. 2 (2012): 97-114. DOI. (C) 2012 Taylor $\&$ Francis. Used with permission. 


\title{
The Ethics of Lobbying: Testing an Ethical Framework for Advocacy in Public Relations
}

\author{
Kati Tusinski Berg \\ J. William and Mary Diederich College of Communication, \\ Marquette University \\ Milwaukee, WI
}

\section{Abstract:}

This study evaluates the ethical criteria lobbyists consider in their professional activities using Ruth Edgett's model for ethically desirable public relations advocacy. Data were collected from self-administered surveys of 222 registered lobbyists in Oregon. A factor analysis reduced 18 ethical criteria to seven underlying factors describing lobbyists' ethical approaches to their work. Results indicate that lobbyists consider the following factors in their day-to-day professional activities: situation, strategy, argument, procedure, nature of lobbying, priority, and accuracy. This framework, derived from Edgett's 10 criteria, illustrates the importance of context while incorporating ideas from recognized ethical theories.

Even though lobbying is often considered a specialization of public relations (Toth, 1986; Heath \& Cousino, 1990; Guth \& Marsh, 2000; Cutlip, Center, \& Broom, 2000), it has received very little attention in the public relations literature (Terry, 2001a, 2001b; Wise, 2007). Yet as an accepted and legal process, political scientists have long recognized the legitimate uses of lobbying in a democracy. Wise explains that "although lobbying has been the topic of considerable research in the political science literature, public relations scholars 
have not displayed a similar degree of interest in the field" (p. 358). Public relations should claim lobbying as its own and continue to develop research that addresses the theoretical, ethical, and communication implications of this activity. This study address the connection between lobbying and public relations in the service of advocacy and the ethics associated with such work.

This research fills three visible and important gaps in the current public relations body of knowledge. First, it studies a specialized group of public relations practitioners that has yet to be examined in depth. Second, it continues to develop advocacy as an ethically desirable function of public relations, building on previous work of Fitzpatrick and Bronstein (2006), Bivins (2006), Edgett (2002), and McBride (1989). Finally, it furthers the development of public relations, particularly lobbying, as a profession by questioning the ethics of such work, similar to research by Bales (1989), Bivins (1989), and Seib and Fitzpatrick (1995) on professionalism and ethics.

\section{CONNECTING LOBBYING, PUBLIC RELATIONS AND ADVOCACY}

Advocacy is a central function of both public relations and lobbying (Arroyo, Connor, Gardner, Lacovar, \& McCarthy, 2002; Barney \& Black, 1994; Bivins, 1987; Mayhew, 1997; McBride, 1989). Terry (2001a) points out that larger collectivities look to lobbyists as "communication professionals to represent their public policy interests and concerns within a political culture that individual voices may be less empowered to navigate on their own" (p. 266). The American League of Lobbyists ( $A L L$ ), the national professional association dedicated exclusively to lobbying, defines lobbying as "advocacy of a point of view, either by groups or individuals" (ALL, n.d.). The Capitol Club, a professional association of state lobbyists in Oregon, describes itself as "an organization of professional advocates" (Capitol Club, 2001).

Despite its historical ambivalence, the field of public relations has begun to embrace its advocacy function. In 2000 the Public Relations Society of America (PRSA) recognized advocacy as one of its core values of public relations. The PRSA code states that practitioners "provide a voice in the marketplace of ideas, facts, and viewpoints to 
aid informed public debate" (PRSA, n.d.). The code also suggests that practitioners serve as "responsible advocates" but fails to elaborate on what responsible advocacy may look like in actual practice (Fitzpatrick \& Bronstein, 2006). In their book Ethics in Public Relations:

Responsible Advocacy, Fitzpatrick and Bronstein offer a collection of essays that begin to create a definitional framework for responsible advocacy: "Ethical guideposts for responsible advocacy in public relations in the twenty-first century will include individual accountability, informed decision making, multicultural understanding, relationship building, open communication, dialogue, truth and transparency, and integrity" (p. xi).

Thus, the connection between lobbying and public relations emerges in the service of advocacy and the ethics associated with such work. In this study, I use Edgett's (2002) definition of advocacy as "the act of publicly representing an individual, organization, or idea with the object of persuading targeted audiences to look favorably on-or accept the point of view of-the individual, the organization, or the idea" to define lobbying (p. 1). Oregon state lobbyists agree that this definition describes their day-to-day professional activities. ${ }^{*}$

\section{THE ETHICS OF PERSUASION}

Scholarly literature suggests lobbyists use persuasion when they advocate on behalf of an organization, a person, or an issue (Milbrath, 1960; Berry, 1977; Zorack, 1990). In her book Ethics in Public Relations, Parsons (2004) suggests that how people go about persuading others to their point of view is what "makes advocacy and persuasion bull's eyes for ethical quagmires" (p. 105). According to Parsons, the advocacy role of public relations has been misunderstood and maligned for years ever since Edward Bernays referred to it as the "engineering of public consent" (p. 106). Nevertheless, persuasion does not necessarily equate to propaganda and manipulation.

\footnotetext{
* The current study was part of my dissertation, which examined lobbying as advocacy public relations, evaluated the roles lobbyists perform in their day-to-day professional work and compared such roles to traditional public relations research, and evaluated the ethical criteria lobbyists consider in their professional activities. Results indicate that lobbyists define their work as advocacy as defined by Edgett (2002). My research also found that despite performing all four public relations roles (communication manager, senior adviser, media relations, and communication technician), both full-time and part-time lobbyists more frequently engage in communication management activities than traditional communication technician tasks.

Journal of Mass Media Ethics, Vol. 27, No. 2 (2012): pg. 97-114. DOI. This article is (C) Taylor \& Francis (Routledge) and permission has been granted for this version to appear in e-Publications@Marquette. Taylor \& Francis (Routledge) does not grant permission for this article to be further copied/distributed or hosted elsewhere without the express permission from Taylor \& Francis (Routledge).
} 
Consequently, public relations techniques, particularly lobbying, rely on the tradition of rhetoric as the foundation for persuasive discourse. Even though a number of scholars insist ethical persuasion and ethical advocacy is achievable (Black, 2001; Baker \& Martinson, 2002; Cunningham, 2001; Edgett, 2002), others disagree (Jackall, 1988; Jackall \& Hirota, 2000), for example, taking a much more critical perspective on the advocacy function of public relations. "Public relations men and women are simply storytellers with a purpose in the free market place of ideas, advocates of a certain point of view in the court of public opinion" (Jackall, p. 185). Jackall and Hirota cast public relations advocates as image-makers who refract, invert, and distort reality in a funhouse-mirror fashion through subtle, disguised, and complex ways.

It is inevitable that the comparison of public relations practitioners to lawyers will come up when discussing ethical behavior and professional standards, both in favor of and against ethical public relations. Jackall (1988) explains:

Alternatively, and by contrast, practitioners in both [agency and corporate] settings sometimes justify their efforts by appealing to a professional ethos that celebrates the exercise of technical skill separated from any emotional commitment to one's clients. A dignified version of this legitimation is the often repeated analogy between public relations practitioners and lawyers. ( $p$. 185)

In a sense, the attorney-adversary model and advocacy mirror each other. The attorney-adversary model locates virtue in the professional values of the individual; the advocacy model locates virtue in public opinion. Advocates do not disclose everything that publics might need or want to know because they have no obligation to do so, just as a lawyer has no obligation to tell everything in a court of law (Grunig \& Grunig, 1996). Ethics can either emerge from practitioners or from the general public. It becomes an argument about sender and receiver, producer and consumer: Should practitioners provide ethical decisions or should the public be responsible to make these judgments? 


\section{A MODEL FOR ADVOCACY}

In the past decade, many scholars have examined public relations ethics by exploring the ethics of persuasion (Black, 2001; Baker \& Martinson, 2002; Cunningham, 2001; Edgett, 2002). Since persuasion is "a recognized and respected communication technique," Bivins (2004) argues, "we must accept that ethical persuasion is a legitimate approach to coming to grips with different points of view" (p. 164).

Edgett (2002) based her framework for ethical advocacy in public relations on the following three premises: advocacy is a central function of public relations, public relations practitioners are uncomfortable with their roles as advocates, and persuasiveness in communication is not inherently wrong. She defines advocacy as "the act of publicly representing an individual, an organization or an idea with the object of persuading targeted audiences to look favorably onor accept the point of view of-the individual, the organization or the idea" (Edgett, p. 1). She also argues that advocacy is neither good nor bad, depending on its implement and application. Edgett proposes the following 10 criteria for ethical advocacy:

1. Evaluation-Detached or objective evaluation of the issue-clientorganization before determining whether it merits public relations advocacy.

2. Priority-Once the public relations practitioner has assumed the role of advocate, the interests of the client or organization are valued above those of others involved in the public debate.

3. Sensitivity-Balancing of client priority on the one hand with social responsibility on the other.

4. Confidentiality-Protection of the client's or organization's rights to confidentiality and secrecy on matters for which secrets are morally justified.

5. Veracity-Full truthfulness in all matters; deception or evasion can be considered morally acceptable only under exceptional circumstances when all truthful possibilities have been ruled out; this implies trustworthiness. 
6. Reversibility-If the situation were reversed, the advocate-clientorganization would be satisfied that it had sufficient information to make an informed decision.

7. Validity-All communication on behalf of the client or organization are defensible against attacks on their validity.

8. Visibility-Clear identification of all communication on behalf of the client or organization as originating from that source.

9. Respect-Regard for audiences as autonomous individuals with rights to make informed choices and to have informed participation in decisions that affect them; willingness to promote dialogue over monologue.

10. Consent-Communication on behalf of the client or organization is carried out only under conditions to which it can be assumed all parties consent. (p. 22)

If practitioners meet all of the criteria, Edgett believes they can be assured that their efforts are ethical. If their practices do not meet any of the outlined criteria, their standards of ethics are much too lax. Therefore, the number of criteria practitioners meet can be used to measure how much remedial work needs to be done to improve their ethical standards. Thus, a set of objective criteria for practitioners to gauge the ethical desirability of their actions is provided (p. 23).

To date, this model has not been tested. Edgett (2002) admits that "further research is needed to determine the practical applicability of the criteria and whether this list is complete and appropriate as it applies to the advocacy function" (p. 23).

\section{METHOD}

The current survey asked respondents how often they consider different criteria when engaged in professional activities regarding clients, communication practices, audiences, and general practices of lobbying. Respondents were asked 18 Likert-type questions, each scored on the following 7-point scale:

1 Never

\section{Almost never}

Journal of Mass Media Ethics, Vol. 27, No. 2 (2012): pg. 97-114. DOI. This article is (C) Taylor \& Francis (Routledge) and permission has been granted for this version to appear in e-Publications@Marquette. Taylor \& Francis (Routledge) does not grant permission for this article to be further copied/distributed or hosted elsewhere without the express permission from Taylor \& Francis (Routledge). 
NOT THE PUBLISHED VERSION; this is the author's final, peer-reviewed manuscript. The published version may be accessed by following the link in the citation at the bottom of the page.

3 About $25 \%$ of the time

4 About half the time

5 About $75 \%$ of the time

6 Almost always

7 Always

This scale was chosen because it quantifies how often respondents consider the various criterion for ethically desirable public relations advocacy in their professional activities as lobbyists. Polich (1974) used this scale in his national survey of newspaper support of press councils. Since most research articles do not include survey questions, other studies that employed such a scale are unknown. However, communication research often employs a 7-point Likert scale with endpoints of "never" and "always."

The first 14 questions of the survey correlate with Edgett's (2002) 10 criteria for ethically desirable public relations advocacy. The first question relates to Edgett's criterion of evaluation defined as "detached, or objective, evaluation of the issue-client-organization before determining whether it merits public relations advocacy" (Edgett, p. 22). To measure lobbyists' view on evaluation, they responded to the following question: "When determining whether to take on a new client or issue, how often do you evaluate the issue, client, or organization to decide if it merits your service?"

The second question measures the criterion of priority, as described by Edgett (2002): "Once the public relations practitioner has assumed the role of the advocate, the interests of the client or organization are valued above those of others involved in the public debate" (p. 22). Respondents responded to the following question to measure their view on priority: "In your day-to-day professional activities, do you consider the interests of those you represent the driving force in your decision making?"

Questions three and four measure Edgett's criterion of sensitivity. Sensitivity is defined as the "balancing of client priority on the one hand with social responsibility on the other" (p. 22). To measure this criterion, respondents responded to the following questions: "Assuming your first loyalty is to those you represent, do permission has been granted for this version to appear in e-Publications@Marquette. Taylor \& Francis (Routledge) does not grant permission for this article to be further copied/distributed or hosted elsewhere without the express permission from Taylor \& Francis (Routledge). 
NOT THE PUBLISHED VERSION; this is the author's final, peer-reviewed manuscript. The published version may be accessed by following the link in the citation at the bottom of the page.

you consider the effects on other interests? How often do you make clients aware of these effects?"

The fifth question relates to Edgett's criterion of confidentiality, which is described as "protection of the client's or organization's rights to confidentiality and secrecy on matters for which secrets are morally justified" (p. 22). Respondents were asked the following question to measure their view on confidentiality: "As a lobbyist, how often do you enact a practitioner-client privilege in which you promise protection of legitimately confidential information (such as employee records, trade secrets, and matters of national security)?"

Question six measures lobbyists' views on veracity. Edgett (2002) defines veracity as "full truthfulness in all matters; deception or evasion can be considered morally acceptable only under exceptional circumstances when all truthful possibilities have been ruled out; this implies trustworthiness" (p. 22). Respondents were asked: "Do you provide policymakers with full disclosure?"

The next three questions (seven, eight and nine) measure the criterion of reversibility: "If the situation were reversed, the advocateclient-organization would be satisfied that it had sufficient information to make an informed decision" (Edgett, 2002, p. 22). To measure lobbyists' view on reversibility, they were asked to respond to the following questions: "When lobbying, how often do you provide the opposing point of view to the issue you are supporting as part of your pitch? How often is such information included for strategic purposes? How often do you feel obligated to include such information out of respect for the person you are lobbying?"

Questions 10 and 11 relate to Edgett's (2002) criterion of validity: "All communications on behalf of the client or organization are defensible against attacks on their validity" (p. 22). To measure lobbyists' view on validity, respondents responded to the following questions: "When communicating on behalf of those you represent, do you present arguments based on reasoning and facts alone? When communicating on behalf of those you represent, do you rely on emotional appeals to gain audience support?"

The next question measures the criterion of visibility in Edgett's (2002) criteria for ethically desirable public relations advocacy. Visibility is defined as "clear identification of all communications on

Journal of Mass Media Ethics, Vol. 27, No. 2 (2012): pg. 97-114. DOI. This article is (C) Taylor \& Francis (Routledge) and permission has been granted for this version to appear in e-Publications@Marquette. Taylor \& Francis (Routledge) does not grant permission for this article to be further copied/distributed or hosted elsewhere without the express permission from Taylor \& Francis (Routledge). 
behalf of the client or organization as originating from that source" (Edgett, p. 22). Respondents were asked: "When lobbying, do you conceal the identity of the group(s) you represent for certain communications?"

Question 13 relates to Edgett's (2002) criterion of respect, which is defined as "regard for audiences as autonomous individuals with rights to make informed choices and to have informed participation in decisions that affect them; willingness to promote dialogue over monologue" (p. 22). To measure lobbyists' view on respect, they were asked to respond to the following question: "When working with policymakers, how often do you see them as means to a successful lobbying campaign?"

Edgett's (2002) criterion of consent, described as "communication on behalf of the client or organization is carried out only under conditions to which it can be assumed all parties consent" (p. 22), is measured by question 14. Respondents were asked: "As a lobbyist, when you interact with policymakers are there understood conditions of conduct?"

Questions 15 and 16 relate to the concept of autonomy. Autonomy, or the capacity to make independent decisions, is not one of Edgett's criteria for ethically desirable public relations advocacy but is measured because one's degree of autonomy affects ethical decision making (Bivins, 2006). To measure lobbyists' degree of autonomy, respondents responded to the following questions: "Do you make lobbying decisions for the group(s) you represent on your own? Do you consult those you represent before making lobbying decisions?"

The final two questions (17 and 18) were included to further measure veracity: "Full truthfulness in all matters; deception or evasion can be considered morally acceptable only under exceptional circumstances when all truthful possibilities have been ruled out; this implies trustworthiness" (Edgett, 2002, p. 22). Respondents were asked: "How often have you purposefully provided legislators with incomplete information to influence their decisions? How often have you purposefully provided legislators with inaccurate information to influence their decisions?" 
NOT THE PUBLISHED VERSION; this is the author's final, peer-reviewed manuscript. The published version may be accessed by following the link in the citation at the bottom of the page.

\section{Treatment of Data}

To determine what ethical criteria lobbyists consider in their day-to-day professional activities, a factor analysis was computed to reduce a large number of variables to a smaller number of factors. Eighteen items were reduced to seven factors.

\section{Respondent Profile}

Data were collected through self-administered questionnaires that were sent to all registered lobbyists $(\mathrm{N}=719)$ in the state of Oregon. In total, 222 responses were received, resulting in a $32.5 \%$ response rate. Table 1 provides a summary of the actually mailing and response rates.

A demographic profile of the respondents is found in Table 2. Of the total respondents, $66.2 \%$ were men and $33.7 \%$ were women. Nearly all of the respondents, $93.7 \%$, identified themselves as White/Anglo. Four percent of the respondents identified themselves as Black/African-American, Hispanic/Latino, or Asian/Pacific Islander. The majority of the respondents were over the age of 40 . The respondents to the current study are well educated, with more than $90 \%$ of the respondents earning a bachelor's degree or higher. More than half $(51.8 \%)$ reported earning an advanced degree: $25.2 \%$ reported earning a master's degree and $26.6 \%$ reported earning a Ph.D., M.D., or J.D.

An occupation profile of the respondents is found in Table 3. More than one-third of the respondents to the current survey reported their current organizational setting as a nonprofit organization. Other respondents identified their current organization setting as public sector $(23 \%)$, lobbying firms $(13.5 \%)$, corporations $(10.8 \%)$, and university $(4.5 \%)$. Only $5 \%$ of the respondents reported their current organizational setting as either a public affairs agency or a public relations agency. Other organizational settings included unions, law firms, trade associations, state agency, consulting firm, community college, public corporation, and health care professional association $(10.8 \%)$.

Only $5 \%$ of the respondents reported public relations as their current job title, $20 \%$ of the respondents reported being contract lobbyists, and $19 \%$ reported their current job title as public affairs. 
The majority of respondents (55.7\%) marked "other" as their current job title. More than 35 different job titles, including director, governmental relations, attorneys, and elected officials, were reported by respondents.

Only nine respondents reported being members of the PRSA; yet more than $60 \%$ of the respondents belong to the Capitol Club, a professional association of state lobbyists in Oregon. Forty-three percent of the respondents reported being members of other professional organizations, with the Oregon State Bar being reported the most.

More than $63 \%$ of the respondents reported some kind of formal ethics training. However, the scope and nature of the ethics training varied tremendously. The responses were categorized into the following groups: education-related (college courses, graduate school and law school), professional organizations (Oregon State Bar and Capitol Club), employer (corporations and agencies), and state agencies (State Government Standards \& Practices Commission and State of Oregon).

\section{RESULTS AND DISCUSSION}

The research question asked what ethical criteria lobbyists consider in their day-to-day professional activities. Since 18 variables were examined, a factor analysis was conducted to determine the underlying structure that explains this set of variables. Factor analysis consists of factor loadings, which is interpreted as the Pearson coefficient of an original variable with a factor. Loadings range from -1.00 (perfect negative association with the factor) through +1.00 (perfect positive association). A factor analysis was computed to reduce a large number of variables to a smaller number of factors. Findings revealed that the ethical criteria lobbyists most often consider relate to seven underlying dimensions: situation, strategy, procedure, nature of lobbying, argument, accuracy, and priority. A principle components factor analysis using oblique rotation, a simple structure to determine what name should be assigned to the factors, was conducted on the variables to determine if the criteria could be grouped into categories or types. The Promax procedure allowed for a nonorthogonal rotation of selected factors. The results of the factor analysis are shown in Table 4.

Journal of Mass Media Ethics, Vol. 27, No. 2 (2012): pg. 97-114. DOI. This article is @ Taylor \& Francis (Routledge) and permission has been granted for this version to appear in e-Publications@Marquette. Taylor \& Francis (Routledge) does not grant permission for this article to be further copied/distributed or hosted elsewhere without the express permission from Taylor \& Francis (Routledge). 


\section{Factor 1: Situation}

Three ethical criteria most clearly loaded on the first factor: evaluate issue, client, or organization (5.74); consideration of effects (5.62); and inform clients of such effects (5.97). This factor represents ethical criteria related to how lobbyists approach specific lobbying situations and/or issues. Factor 1 explains $18.8 \%$ of the total variance. The Eigen value for this factor is 3.38 .

These three criteria all generated relatively high levels of ethical consideration among respondents (mean ethical consideration range from 5.69 to 5.97 , where $1=$ never and 7 = always). This factor addresses the ethical framework lobbyists use to approach particular lobbying situations and/or issues. One of the criteria indicates that lobbyists first evaluate the issue, client, or organization to decide if it merits their service. If it does, lobbyists then consider the effects of the lobbying issue on other interests and make the client(s) aware of potential effects.

Because lobbying fits under the agency model of professionalclient relationship, it requires professionals to engage in a process of evaluation to recuperate some of their autonomy (Bivins, 2006). The factor of situation outlines the ethical framework lobbyists use to approach particular lobbying situations and/or issues. This factor supports Bivins's process of evaluation. Bivins (2006) notes that if the professional engages in a process of assessment before accepting a client or an issue, the function of advocacy can remain a professional role responsible to client interests, professional interests, and thirdparty interests (p. 27). Findings from the current study indicate that more than $75 \%$ of the time lobbyists engage in an evaluation process before determining whether to take on a new client or interest. After lobbyists engage in the initial evaluation of the issue, client, or organization, effects on other interests are considered and clients are made aware of such effects.

\section{Factor 2: Strategy}

Factor 2 includes four criteria related to the strategy of lobbying, including: provide opposing point of view (5.12), include for strategic purposes (5.44), include out of respect (5.22), and identify 
groups represented (6.69). This factor explains $10.3 \%$ of the total variance. The Eigen value for this factor is 1.86 .

Several of the criteria included in Factor 2 indicate that lobbyists tend to include the opposing point of view as part of their strategy and out of respect for the person being lobbied. The final criterion that loaded on this factor reveals that lobbyists rarely conceal the identity of their clients as part of the strategic plan. The four criteria loaded on Factor 2 generated moderately high levels of ethical consideration (means from 5.12 to 6.69).

The factor of strategy includes elements of reversibility, respect, and visibility. This factor follows the adage "do unto others as you would have them to do unto you" or "communicate with others as you would have them communicate with you" (Edgett, 2002, p. 17). It is not surprising that these criteria loaded together because they all relate to the importance of respect to ethical advocacy. Furthermore, Edgett cross-references the explanations of these three criteria because they are based on similar ethical theories. For example, Kant's categorical imperative is used to describe both reversibility and respect: "Thus, in the case of information about a particular issue, a practitioner would be obligated to picture him or herself as the audience and to ask the question whether sufficient information had been provided to allow informed choice on the part of the receiver" ( $p$. 18). Moreover, the factor of strategy requires lobbyists to respect "audiences as autonomous individuals who are capable of making wellformed decisions based on complete information" (p. 20). Even though lobbyists tend to provide the opposing point of view as part of their strategic plan, this factor encourages lobbyists to do so in a way that respects audiences and clearly identifies their clients.

\section{Factor 3: Procedure}

Two criteria loaded on Factor 3: make decisions on own (3.63) and consult those represented (5.71). This factor addresses the procedural aspects of making lobbying decisions. This factor is less situational than the first two factors and draws attention to the way in which lobbyists conduct business. This factor bridges the gap between micro issues and the macro environment (see Figure 1). Factor 3 explains $8.5 \%$ of the variance. The Eigen value for this factor is 1.54 . 
As previously mentioned, findings from the current study confirm that lobbying fits well into the agency model of professionalclient relationship. Respondents indicated that they consult the clients they represent before making lobbying decisions (mean $=5.71$ ) more often than they make lobbying decisions for the group(s) they represent on their own (mean $=3.63$ ). Since lobbyists perceive themselves as advocates and lobbying fits under the agency model of the professional-client relationship, it is not surprising for lobbyists to experience a reduction in their autonomy. In such circumstance, the order in which lobbyists make decisions is most important:

This ordering of stages from the objective to the subjective will allow the professional public relations practitioner to perform all the necessary functions ascribed to the roles of the profession without either falling into the trap of ideological advocacy or succumbing to a less autonomous position. (Bivins, 2006, p. 28)

\section{Factor 4: Nature of Lobbying}

Two criteria loaded on Factor 4: protect confidentiality (4.31) and understood conditions of conduct (6.52). Because this factor addresses the macro environment in which lobbyists work, it is referred to as the nature of lobbying. Factor 4 explains $7.6 \%$ of the total variance. The Eigen value for this factor is 1.37 . This factor indicates that the nature of lobbying lends itself to certain behaviors. For example, the relatively high mean (6.52) of the second criteria loaded in this factor indicates that there are understood conditions of conduct between lobbyists and policymakers. Because a legislative vote can make or break a lobbying effort, it is necessary for both lobbyists and legislators to understand the adversarial relationship this environment creates.

\section{Factor 5: Argument}

Factor 5 includes criteria that address the validity of the arguments. Two criteria loaded on the fifth factor are use of reasoning and facts and reliance on emotional appeals. Factor 5 explains $6.2 \%$ of the variance. The Eigen value for this factor is 1.11 . The mean scores of these two criteria (5.46 and 4.65) indicate that lobbyists use a combination of facts and emotional appeals to gain audience support. 
The factor of argument reflects Aristotle's definition of rhetoric as the ability, in each particular case, to see the available means of persuasion (Kennedy, 1991, p. 36). This factor suggests that lobbyists use a combination of facts and emotional appeals to gain audience support, which supports Aristotle's notions of pathos, logos, and ethos. However, this finding conflicts with Edgett's (2002) assertion that "arguments presented by public relations practitioners must be based on sound reasoning" (p. 18). Jensen (1997) admits that "reason and emotion are difficult to separate and are normally intertwined" (p. 96). Ultimately, Jensen advises public relations practitioners not to use emotional arguments because this type of reasoning manipulates audiences by limiting their ability to make informed decisions.

Still, emotional appeals are not inherently unethical. Bivins (2004) explains that emotional arguments may be manipulative and thus unethical only if the true objective of the message, to persuade, is hidden. Lobbyists can use responsible rhetorical techniques when interacting with legislators because there are understood conditions of consent. Results of the current study indicate that lobbyists use a combination of facts and emotional appeals when communicating on behalf of those they represent, and that they tend to use the latter less frequently. The factor of argument illustrates that lobbyists consider the validity of their arguments and the context in which they are implementing rhetorical techniques.

\section{Factor 6: Accuracy}

Three criteria loaded on Factor 6: provide full disclosure (6.15), provide accurate information (6.96), and provide complete information (6.50). This factor addresses the importance of providing legislators with complete and accurate information. Factor 6 explains $6.1 \%$ of the total variance, and the Eigen value for this factor is 1.10 . These three criteria generated rather high levels of ethical consideration among respondents (mean ethical range from 6.15 to 6.96) demonstrates the importance of truthfulness and trustworthiness, Edgett's criteria of veracity.

This factor represents how lobbyists present issues to decision makers. The three criteria that loaded on this factor relate to the way in which lobbyists interact with legislators. Providing full disclosure and complete information correspond with Edgett's (2002) criterion of 
veracity, which she defines as full truthfulness in all matters. She explains, "When the speaker (or communicator) lies, not only has he or she violated the time-honored principle of telling the truth, he or she has broken the implied promise to tell the truth" (p. 17). These criteria demonstrate that "ethically defensible advocacy would not resort to deceit because misconstruing important fact would amount to depriving the receiver of significant choice" (p. 15). It is important to note that "true completeness is usually impossible, unrealistic, and at times even undesirable in human communicative transactions" (Jensen, 1997, p. 88).

This factor illustrates that lobbyists understand the ramifications of providing inaccurate or incomplete information to legislators. Not only will it damage their professional reputations, but such behavior also could result in negative public policy evaluation. Jensen (1997) explains, "The great harms that lying can cause the deceived, the deceiver, and the larger society are many and significant" (p. 88). This factor reflects the importance of truthfulness and trustworthiness.

\section{Factor 7: Priority}

Factor 7 includes two criteria related to the priority of those lobbyists represent: the consideration of the interests of those you represent as the driving force in decision making (6.27) and view as means to success (2.45). The relatively high mean of the first criteria (6.27) indicates that client interests are the driving force when lobbyists make decisions. In addition, lobbyists almost always (2.45) see policymakers as means to a successful lobbying campaign. Factor 7 explains $5.5 \%$ of the total variance, and the Eigen value for this factor is 0.98 . These factors clearly indicate that priority to client interests must be considered constantly during the lobbying process.

Again, this factor reflects the agency model of the professionalclient relationship. As advocates, lobbyists take up the cause of their clients and work "zealously" to promote that cause (American Bar Association). Bivins (2004) notes that "part of the assumption of advocacy is that the advocate take up his clients' cause fully, without regard to his own feelings" (p. 60). Yet Edgett (2002) argues that since advocacy is a legitimate function of public relations, "it may well be possible for practitioners to take on the advocate's role without sacrificing the moral good" (p. 8). 
Results indicate that even though lobbyists perceive policymakers as means to successful lobbying campaigns, this attitude is not inherently unethical because legislators have a vested interest in their relationships with lobbyists and willingly volunteer to the conditions of participation. Thus, speech by lobbyists directed toward legislators is considered noncoercive because legislators are aware of their options and retain free choice (Bivins, 2006; Baker, 1992). This factor illustrates that even though lobbyists use legislators as a means to an end, the lobbyists' behavior is not unethical because the process is transparent.

In summary, a factor analysis revealed that lobbyists consider seven factors in their day-to-day professional activities. These factors were labeled situation, strategy, procedure, argument, nature of lobbying, accuracy, and priority. This framework, derived from Edgett's 10 criteria, illustrates the importance of context while incorporating ideas from recognized ethical theories.

\section{IMPLICATIONS AND CONCLUSION}

The purpose of this study was to evaluate the ethical criteria lobbyists consider in their day-to-day professional activities by using Edgett's (2002) model for ethically defensible advocacy in public relations. This study systematically and scientifically examined attitudes and practices of a specialized group of public relations practitioners. Specifically, this research found that lobbyists approach ethics from a contextual perspective. These findings contribute to the development of advocacy as an ethically desirable function of public relations (Bivins, 2006; Edgett; McBride, 1989) and to the emerging professionalism of public relations, more specifically to the professionalism of lobbying.

\section{Implications for Theory: Public Relations Ethics}

Public relations ethics has intensified as an area of research in communication because both practitioners and scholars realize that it may be "the greatest challenge facing the field" (Seib \& Fitzpatrick, 1995, p. 4). Discussing public relations ethics proves to be complex due to the field's distinct heritages, multiple responsibilities of practitioners, and the lack of a universalized definition for public relations. Moreover, Tusinski (2002) concluded that ethical norms for public relations practices cannot easily be located in the function or the permission has been granted for this version to appear in e-Publications@Marquette. Taylor \& Francis (Routledge) does not grant permission for this article to be further copied/distributed or hosted elsewhere without the express permission from Taylor \& Francis (Routledge). 
history of public relations. Further, professional codes of ethics and accreditation programs do not address all ethical issues. This study supports Curtin and Boynton's (2001) argument that one's definition of public relations can determine one's ethical practice. Lobbyists in Oregon defined their work as advocacy and approached ethics from a contextual perspective that supports the agency model of the professional-client relationship.

Likewise, every theory of public relations ethics assumes a model of public relations practice. Because lobbyists define their work as advocacy, their approach to ethical behavior differs from public relations practitioners who perceive themselves as counselors. When making lobbying decisions, Oregon lobbyists consult those they represent more often than they make lobbying decisions on their own. This research confirms advocacy's fit with the agency model of professional-client relationship and creates a framework to further discuss the ethical implications of such a model.

Yet the ethical framework presented illustrates the significance of context for advocacy public relations. Lobbyists structure ethical criteria around factors that enable them to meet their clients' needs while fulfilling obligations to legislators and protecting the lobbyists' reputations. These factors are divided into micro factors (situation, strategy, and argument) and macro factors (nature of lobbying, information, and priority). The final factor of procedure bridges the gap between the micro and macro ethical issues. This contextual approach to ethics may be applicable to other advocacy-oriented public relations specialties, such as nonprofit work and health communication.

\section{Ethics and Professionalism}

The literature on professionalism and public relations reflects the field's desire to become a profession. For instance, Bivins (2004) notes that "public relations has been striving for 50 plus years to gain acceptance as a profession" (p. 52). Yet many scholars and practitioners continue to develop a body of knowledge, a standard of norms, and an ethical theory to confirm the field's professional status. The current study demonstrates that lobbyists have a standard of norms. Lobbyists know that providing inaccurate information to legislators is unacceptable because relationships are built on trust. Furthermore, there are understood conditions of conduct between 
lobbyists and legislators that foster acceptable behavior and discourage improper activities.

According to ethicist Michael Bales (1989), three characteristics are necessary for professional status: extensive training, significant intellectual component, and important service to society (p. 7). Most professions possess secondary features including credentialing, a professional organization, and autonomy.

Even though, public relations has many of these characteristics, its status as a profession is still uncertain because many practitioners, as seen in this study, do not possess a high level of autonomy. "Autonomy is necessary from a philosophical perspective to enable rational ethical decision making uninfluenced by subjective concerns" (Bowen, 2000, p. 457). However, Bowen's research emphasizes public relations as ethics counsel to issues management in organizations rather than the advocacy function of public relations in the agency model of the professional-client relationship. Findings from the current research study demonstrate that, despite resigning some of their autonomy, advocates still consider ethical factors in their professional work.

\section{Conclusion}

A main limitation of this study is that it was conducted in a single state, Oregon. An evaluation of the public relations industry, the political environment, and the lobbying scene in Oregon suggests that certain governmental procedures (i.e., a biennial legislature) may provide a unique environment for lobbying. To be able to further generalize the results of this study, the self-administered mail survey could be sent to a random sample of registered lobbyists in multiple states.

The overall response rate of $32 \%$ is acceptable for a mail survey (Wimmer \& Dominick, 2006). Surprisingly, only a handful of respondents chose to respond to the survey via the Internet ( $N=15$ ). Many of the respondents wrote comments on the surveys or contacted me about the survey demonstrating their desire to further engage issues that surfaced from the survey. Therefore, future research should include follow-up interviews because professionals who talk about their work constitute a valuable form of evidence. It would also 
be of value to survey or interview congressional staff members and legislators to discover their views on lobbying practices.

Even with these limitations, the current study has contributed to the public relations body of knowledge in several ways. First, it has examined an overlooked specialized group of public relations practitioners. Next, the study tested Edgett's (2002) model for ethical public relations advocacy. It also provided an extended framework to approach the ethics of advocacy from a contextual perspective. Thus, this study contributes to the development of public relations, particularly lobbying, as a profession.

Furthermore, this research is important because it demonstrates that the information-providing role that lobbyists perform in the public policy arena is underplayed in academic literature while the persuasive aspects of the profession are overemphasized. An exaggerated portrayal of lobbying that fails to embrace its theoretical, legal, and communication foundations is most often accepted in public vernacular. Hopefully, this research stimulates future research that confirms Seib and Fitzpatrick's (1995) description: "Members of a new breed of lobbyists earn their fees based on what they know, rather than whom they know; the emphasis is on process more than personalities" (p. 93). Increasingly, ethical practices are more important for such communication practices. This study provides the insight necessary to continue to research lobbyists as public relations practitioners and the ethics of advocacy public relations. 
NOT THE PUBLISHED VERSION; this is the author's final, peer-reviewed manuscript. The published version may be accessed by following the link in the citation at the bottom of the page.

\section{APPENDIX}

Table 1. Response Rate

Surveys

\# Mailed

\# Completed and Returned

\# Undeliverable

\# Unusable Surveys

Usable Surveys

Response Rate

Total Mailed Surveys

Internet Response Rate

Decline Rate

Undeliverable Rate
719

222

36

0

222

$32.5 \%$

$6.9 \%$

$3.0 \%$

$5.0 \%$

Journal of Mass Media Ethics, Vol. 27, No. 2 (2012): pg. 97-114. DOI. This article is (C) Taylor \& Francis (Routledge) and permission has been granted for this version to appear in e-Publications@Marquette. Taylor \& Francis (Routledge) does not grant permission for this article to be further copied/distributed or hosted elsewhere without the express permission from Taylor \& Francis (Routledge). 
NOT THE PUBLISHED VERSION; this is the author's final, peer-reviewed manuscript. The published version may be accessed by following the link in the citation at the bottom of the page.

Table 2. Respondent Profile: Demographics $(\mathrm{N}=222)$

Variables

Percentage of Respondents

Sex of Respondent

$\begin{array}{ll}\text { Male } & 66.2 \% \\ \text { Female } & 33.8\end{array}$

Age of Respondent (on last birthday)

$\begin{array}{lc}20-29 \text { years old } & 5.0 \% \\ 30-39 \text { years old } & 18.9 \\ 40-49 \text { years old } & 19.4 \\ 50-59 \text { years old } & 41.4 \\ 60-69 \text { years old } & 11.7 \\ 70 \text { years old or older } & 3.6\end{array}$

Race/Ethnicity of Respondent

White/Anglo

$93.7 \%$

Black/African-American $\quad 1.0$

Hispanic/Latino $\quad 1.8$

American Indian/Native American $\quad 0.0$

Asian/Pacific Islander $\quad 1.3$

Other $\quad 1.0$

Prefer Not to Answer $\quad 1.2$

Education Level

High School $\quad 0.4 \%$

Some College $\quad 8.6$

Bachelor's Degree $\quad 39.2$

Master's Degree $\quad 25.2$

Ph.D., M.D., or J.D. $\quad 26.6$

Journal of Mass Media Ethics, Vol. 27, No. 2 (2012): pg. 97-114. DOI. This article is (C) Taylor \& Francis (Routledge) and permission has been granted for this version to appear in e-Publications@Marquette. Taylor \& Francis (Routledge) does not grant permission for this article to be further copied/distributed or hosted elsewhere without the express permission from Taylor \& Francis (Routledge). 
NOT THE PUBLISHED VERSION; this is the author's final, peer-reviewed manuscript. The published version may be accessed by following the link in the citation at the bottom of the page.

Table 3. Respondent Profile: Occupation ( $\mathrm{N}=222)$

Variables

Percentage of Respondents

Organizational Setting

Corporation

$10.8 \%$

Non Profit Organization

31.1

Public Affairs Agency

3.6

Public Sector

23.0

University

4.5

Public Relations Agency

1.4

Lobbying Firm

13.5

Other

10.8

No Response

1.3

Current Job Title

Public Affairs

$19.0 \%$

Public Relations

5.0

Contract Lobbyist

20.3

Other

55.7

Membership in Professional Organizations

American Bar Association

$5.4 \%$

American League of Lobbyists

0.4

American Marketing

0.9

Capitol Club, Inc.

60.0

Public Relations Society of America $\quad 4.0$

Other

17.0

Formal Ethics Training

Yes

$64 \%$

No

$35 \%$

No Response

1.0

Registered as Lobbyist

Highest

Number of Years

Lowest

47

Average

1

10.7

Journal of Mass Media Ethics, Vol. 27, No. 2 (2012): pg. 97-114. DOI. This article is @ Taylor \& Francis (Routledge) and permission has been granted for this version to appear in e-Publications@Marquette. Taylor \& Francis (Routledge) does not grant permission for this article to be further copied/distributed or hosted elsewhere without the express permission from Taylor \& Francis (Routledge). 
NOT THE PUBLISHED VERSION; this is the author's final, peer-reviewed manuscript. The published version may be accessed by following the link in the citation at the bottom of the page.

\section{Table 4 :}

\section{Factor Analysis of Ethical Criteria}

\begin{tabular}{|c|c|c|c|c|c|c|c|c|}
\hline \multirow[b]{2}{*}{ Ethical Criteria } & \multicolumn{2}{|l|}{ Mean } & \multicolumn{6}{|c|}{ Factor Loading } \\
\hline & & 1 & 2 & 3 & 4 & 5 & 6 & 7 \\
\hline \multicolumn{9}{|l|}{ Situation } \\
\hline $\begin{array}{l}\text { When determining whether to take on a new client or issue, } \\
\text { how often do you evaluate the issue, client, or organization } \\
\text { to decide if it merits your service? }\end{array}$ & 5.74 & 583 & .203 & .129 & -.158 & -.233 & .110 & -.014 \\
\hline $\begin{array}{l}\text { Assuming your first loyalty is to those you represent, } \\
\text { do you consider the effects on others? }\end{array}$ & 5.62 & .768 & .139 & .070 & .266 & .098 & .077 & .136 \\
\hline \multicolumn{9}{|l|}{ Strategy } \\
\hline $\begin{array}{l}\text { When lobbying, how often do you provide the opposing } \\
\text { point of view to the issue you are supporting as part } \\
\text { of your pitch? }\end{array}$ & 5.12 & .511 & .603 & .068 & .457 & .084 & .179 & .111 \\
\hline $\begin{array}{l}\text { How often is such information included for strategic } \\
\text { purposes? }\end{array}$ & 5.44 & 318 & .755 & .067 & .202 & -.057 & .171 & .266 \\
\hline $\begin{array}{l}\text { How often do you feel obligate to include such information } \\
\text { out of respect for the person you are lobbying? }\end{array}$ & 5.22 & 330 & .641 & .040 & .328 & .235 & .909 & -.133 \\
\hline $\begin{array}{l}\text { When lobbying, do you conceal the identity of the } \\
\text { group(s) you represent for certain communications? } \\
\text { Procedure }\end{array}$ & 6.69 & .130 & -489 & -.239 & .212 & .169 & .007 & .017 \\
\hline $\begin{array}{l}\text { Do you make lobbying decisions for the group(s) you } \\
\text { represent on your own? }\end{array}$ & 3.63 & .071 & .295 & .806 & .095 & -.032 & .025 & -.107 \\
\hline Do you consult those you represent before making & 5.71 & -.025 & .063 & -.808 & .269 & .107 & .095 & -.071 \\
\hline \multicolumn{9}{|l|}{ lobbying decisions? } \\
\hline \multicolumn{9}{|l|}{ Nature of Lobbying } \\
\hline $\begin{array}{l}\text { As a lobbyist, how often do you enact a practitioner-client } \\
\text { privilege in which you promise protection of legitimately } \\
\text { confidential information (such as employee records, } \\
\text { trade, secrets, and matters of national security)? }\end{array}$ & 4.31 & .065 & .345 & -.100 & .625 & -.202 & -.060 & -.105 \\
\hline $\begin{array}{l}\text { As a lobbyist, when you interact with policymakers are } \\
\text { there understood conditions of conduct? }\end{array}$ & 6.52 & .244 & .015 & -.075 & .779 & .215 & .173 & .159 \\
\hline \multicolumn{9}{|l|}{ Argument } \\
\hline $\begin{array}{l}\text { When communicating on behalf of those you represent, } \\
\text { do you present arguments based on reasoning } \\
\text { and facts alone? }\end{array}$ & 5.46 & -.010 & .129 & .162 & .043 & .756 & .224 & -.020 \\
\hline $\begin{array}{l}\text { When communicating on behalf of those you represent, } \\
\text { do you rely on emotional appeals to gain audience } \\
\text { support? }\end{array}$ & 4.65 & .039 & -.140 & -.252 & .085 & .783 & .046 & -.108 \\
\hline \multicolumn{9}{|l|}{ Accuracy } \\
\hline How often do you provide policymakers with full disclosure? & 6.15 & 505 & .138 & .141 & 338 & .181 & .634 & -.032 \\
\hline $\begin{array}{l}\text { How often have you purposefully provided legislators with } \\
\text { inaccurate information to influence their decisions? }\end{array}$ & 6.96 & -.275 & .074 & -.141 & -.132 & .078 & .619 & .010 \\
\hline $\begin{array}{l}\text { How often have you purposefully provided legislators with } \\
\text { incomplete information to influence their decisions? } \\
\text { Priority }\end{array}$ & 6.50 & 461 & .072 & -.018 & .251 & .155 & .752 & -.071 \\
\hline $\begin{array}{l}\text { In your day-to-day professional activities, do you consider } \\
\text { the interests of those you represent the driving force } \\
\text { in your decision making? }\end{array}$ & 6.27 & 300 & -.057 & .174 & -.045 & -.183 & -.021 & .745 \\
\hline $\begin{array}{c}\text { When working with policymakers, how often do you see } \\
\text { them as means to a successful lobbying campaign? }\end{array}$ & 2.45 & .086 & -.294 & .234 & -.241 & -.086 & .019 & -.707 \\
\hline
\end{tabular}

Journal of Mass Media Ethics, Vol. 27, No. 2 (2012): pg. 97-114. DOI. This article is @ Taylor \& Francis (Routledge) and permission has been granted for this version to appear in e-Publications@Marquette. Taylor \& Francis (Routledge) does not grant permission for this article to be further copied/distributed or hosted elsewhere without the express permission from Taylor \& Francis (Routledge). 
NOT THE PUBLISHED VERSION; this is the author's final, peer-reviewed manuscript. The published version may be accessed by following the link in the citation at the bottom of the page.

FIGURE 1. Bridging the Gap: From Micro Issues to Macro Issues

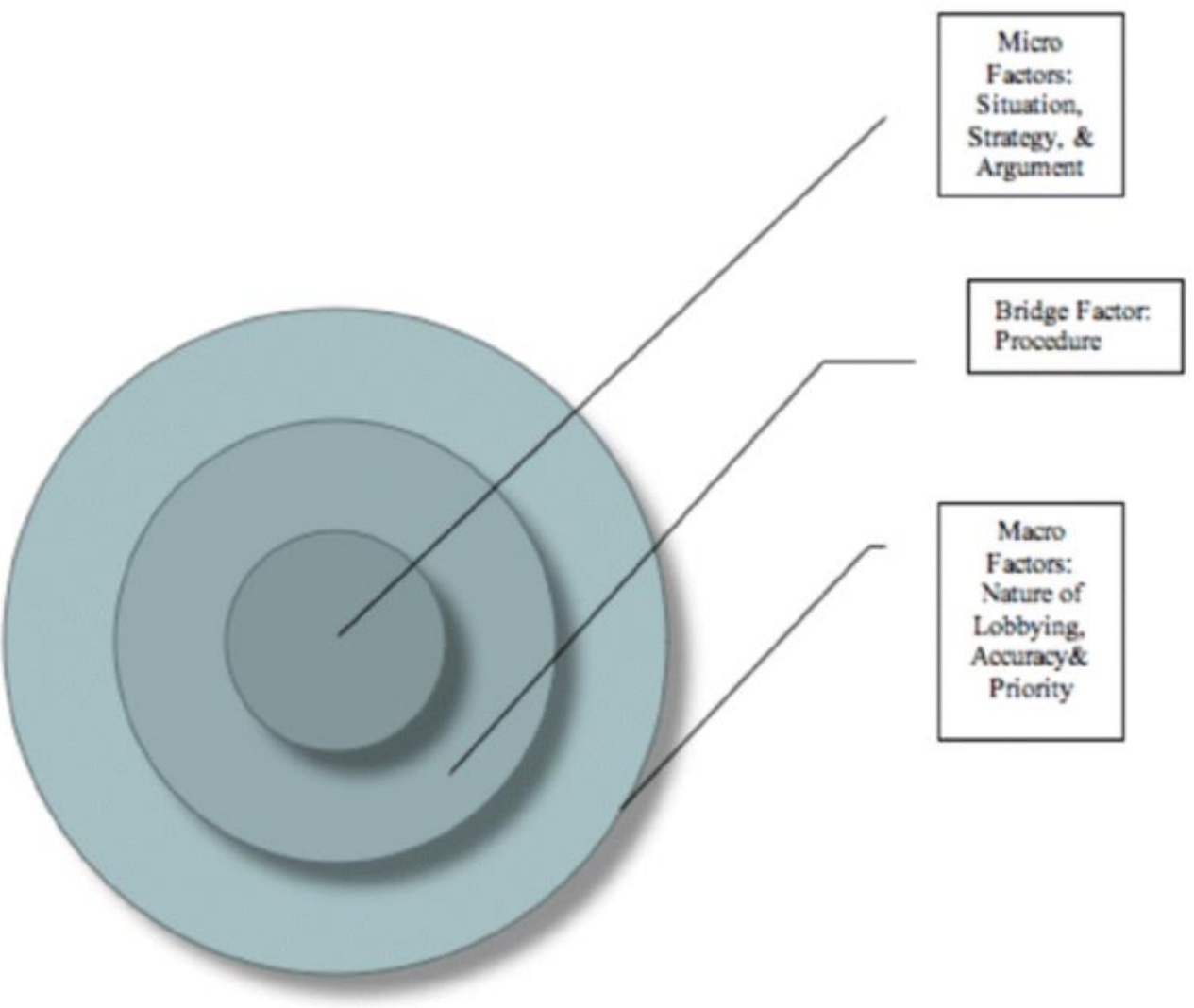

Journal of Mass Media Ethics, Vol. 27, No. 2 (2012): pg. 97-114. DOI. This article is (C) Taylor \& Francis (Routledge) and permission has been granted for this version to appear in e-Publications@ Marquette. Taylor \& Francis (Routledge) does not grant permission for this article to be further copied/distributed or hosted elsewhere without the express permission from Taylor \& Francis (Routledge). 
NOT THE PUBLISHED VERSION; this is the author's final, peer-reviewed manuscript. The published version may be accessed by following the link in the citation at the bottom of the page.

\section{References}

1. American League of Lobbyists. (n.d.). Background on the League. Retrieved February 2, 2005 from http:www.alldc.org/press.htm

2. American League of Lobbyists. (n.d.). American League of Lobbyists' Code of Ethics. Retrieved February 2, 2005 from http:www.alldc.org/ethicscode.htm

3. Arroyo, E. B., Connor, J. L., Gardner, R. W., Lacovar, P. A., \& McCarthy, M. $\mathrm{H}$. (2002). The ethics of lobbying: Organized interests, political power, and the common good. Washington, DC: Georgetown University Press.

4. Baker, C. E. (1992). Human liberty and freedom of speech. New York: Oxford University Press.

5. Baker, S., \& Martinson, D. L. (2002). The TARES test: Five principles for ethical persuasion. Journal of Mass Media Ethics, 16(2\&3), 148-175.

6. Bales, M. D. (1989). Professional ethics (2nd ed.). Belmont, CA: Wadsworth Publishing Company.

7. Barney, R. D., \& Black, J. (1994). Ethics and professional persuasive communications. Public Relations Review, 20(3), 233-249.

8. Berry, J. M. (1977). Lobbying for the people: The political behavior of public interest groups. Princeton: Princeton University Press.

9. Bivins, T. H. (2006). "Responsibility and accountability," In K. Fitzpatrick \& C. B. Bronstein (Eds.), Ethics in public relations: Responsible advocacy. Thousands Oaks, CA: Sage.

10. Bivins, T. H. (2004). Mixed media: Moral distinctions in advertising, public Relations, and journalism. Mahwah, N.J.: L. Erlbaum Associates.

11. Black, J. (2001). Semantics and ethics of propaganda. Journal of Mass Media Ethics, 16(2\&3), 121-137.

12. Bivins, T. H. (1989). Are public relations texts covering ethics adequately? Journal of Mass Media Ethics, 4(1), 39-52.

13. Bivins, T. H. (1987). Applying ethical theory to public relations. Journal of Business Ethics, 6, 195-200.

14. Bowen, S. (2000). A theory of ethical issues management: Contributions of Kantian deontology to public relations' ethics and decision making. Unpublished doctoral dissertation, University of Maryland, College Park.

Journal of Mass Media Ethics, Vol. 27, No. 2 (2012): pg. 97-114. DOI. This article is (C) Taylor \& Francis (Routledge) and permission has been granted for this version to appear in e-Publications@Marquette. Taylor \& Francis (Routledge) does not grant permission for this article to be further copied/distributed or hosted elsewhere without the express permission from Taylor \& Francis (Routledge). 
NOT THE PUBLISHED VERSION; this is the author's final, peer-reviewed manuscript. The published version may be accessed by following the link in the citation at the bottom of the page.

15. Capitol Club, Inc. (2001). Membership Directory 2001 -03. [Brochure]. Salem, OR: Author.

16. Cunningham, S. B. (2001). Responding to propaganda: An ethical enterprise. Journal of Mass Media Ethics, 16(2\&3), 138-147.

17. Curtin, P., \& Boynton, L. (2001). Ethics in public relations: Theories and practice. In R. Heath (Ed.), Handbook of public relations (pp. 411421). Thousand Oaks, CA: Sage.

18. Cutlip, S. M., Center, A. H., \& Broom, G. M. (2000). Effective public relations (8th ed.). Upper Saddle River, NJ: Prentice-Hall.

19. Edgett, R. (2002). Toward an ethical framework for advocacy in public relations. Journal of Public Relations Research, 14(1), 1-26.

20. Grunig, J. E., \& Grunig, L. A. (1996). Implications of symmetry for a theory of ethics and social responsibility in public relations. Paper presented at the Public Relations Interest Group International Communication Association, Chicago, IL.

21. Guth, D., \& Marsh, C. (2000). Public relations: A values-driven approach. Boston: Allyn and Bacon.

22. Heath, R. L., \& Cousino, K. R. (1990). Issues management: End of first decade Progress report. Public Relations Review, 16(1), 7-18.

23. Jackall, R. (1988). Moral mazes: The world of corporate managers. New York: Oxford University Press.

24. Jackall, R., \& Hirota, J. M. (2000). Image makers: Advertising, public relations, and the ethos of advocacy. Chicago: University of Chicago Press.

25. Jensen, J. V. (1997). Ethical issues in the communication process. Mahweh, NJ: Lawrence Erlbaum Associates, Inc.

26. Kennedy, G. (1991). Aristotle on rhetoric: A theory of civic discourse. New York: Oxford University Press.

27. Mayhew, L. H. (1997). The new public: Professional communication and the means of social influence. New York: Cambridge.

28. McBride, G. (1989). Ethical thought in public relations history: Seeking a relevant perspective. Journal of Mass Media Ethics, 4(1), 5-20.

29. Milbrath, L. W. (1960). Lobbying as a communications process. Public Opinion Quarterly, 24(1), 32. permission has been granted for this version to appear in e-Publications@ Marquette. Taylor \& Francis (Routledge) does not grant permission for this article to be further copied/distributed or hosted elsewhere without the express permission from Taylor \& Francis (Routledge). 
NOT THE PUBLISHED VERSION; this is the author's final, peer-reviewed manuscript. The published version may be accessed by following the link in the citation at the bottom of the page.

30. Parsons, P. (2004). Ethics in public relations: A guide to best practices. London: Kogan.

31. Polich, J. E. (1974). Newspaper support of press councils. Journalism Quarterly, 51, 2, 199-206.

32. Public Relations Society of America, Member Code of Ethics. (n.d.) Member Statement of Professional Values. Retrieved December 6, 2005, from http://www.prsa.org

33. Seib, P. \& Fitzpatrick, K. (1995). Public relations ethics. Fort Worth, TX: Harcourt Brace.

34. Terry, V. (2001a). Lobbying: Fantasy, reality or both? A health care public policy case study. Journal of Public Affairs, 1(3), 266-280.

35. Terry, V. (2001b). Lobbyists and their stories: Classic PR practitioner role models as functions of Burkean human motivations. Journal of Public Relations Research, 13(3), 235-263.

36. Toth, E. L. (1986). Broadening research in public relations. Public Relations Review, 13, 27-36.

37. Tusinski, K. (2002). A Critical Analysis of the Literature on Public Relations Ethics. Unpublished master's thesis, Saint Louis University.

38. Wimmer, R. D., \& Dominick, J. R. (2006). Mass media research: An introduction (6th ed.). Belmont, CA: Wadsworth Pub.

39. Wise, K. (2007) "Lobbying and Relationship Management," Journal of Public Relations Research, 19(4): 357-76.

40. Zorack, J. L. (1990). The lobbying handbook. Washington, DC: Professional Lobbying and Consulting Center.

Journal of Mass Media Ethics, Vol. 27, No. 2 (2012): pg. 97-114. DOI. This article is (C) Taylor \& Francis (Routledge) and permission has been granted for this version to appear in e-Publications@Marquette. Taylor \& Francis (Routledge) does not grant permission for this article to be further copied/distributed or hosted elsewhere without the express permission from Taylor \& Francis (Routledge). 